\title{
Population Abundance of the Red Palm Weevil Rhynchophorus ferrugineus (oliv.) Adults on date Palm Plantations in Baharia Oases Giza Governorate - Egypt \\ Hussain, A. E. ; S. F. Elsharabasy $^{2}$; M. M. M. Megahed ${ }^{1}$ and A. R. M. Abd elmagid ${ }^{2}$ \\ ${ }^{1}$ Plant Protection Department, Faculty of Agriculture, Al- Azhar University. \\ ${ }^{2}$ The Central Laboratory of Date Palm Research and Development.
}

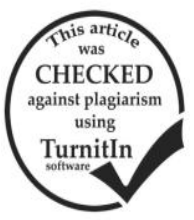

\section{ABSTRACT}

This is the first study on Red Palm Weevil Rhynchophorus ferrugineus (Oliv.) in Baharia Oases. The aim of the present work was to study the population abundance of $R$. ferrugineous (Oliv.) adults in relation to two climatic factors using attracting pheromone traps on date palm plantation. This work was carried out during January 2013 to December 2014 in Baharia Oases, Giza Governorate- Egypt. The obtained results recorded that adults emerging continually throughout the year. The lowest adults population was recorded during January and December in the two tested years, the population showed two peaks of adult population for each year. The first peak in 2013 recorded at the second week of April while the second peak recorded at second week of October. In 2014 the first peak recorded at second week of March and the second peak at the second week of September. There were different effects of daily mean temperature and relative humidity on the population activity of $R$. ferrugineous. The sex ratios of male to female were 1:2.5 and 1: 2.4 during 2013 and 2014 respectively.

\section{INTRODUCTION}

Date palm, (Phoenix dactylifera L.), is one of the oldest fruit trees in the world and is mentioned in the Holy Qur'an. Date palm is one of the most important fruit trees in the Middle East and desert regions of Africa. In some areas, this is the only tree which provides food, shelter and fuel to the communities. Dates are not only a staple food but are also an important export cash crop. (Zaid and Hegarty 2006). Date palm has a great economic importance and agricultural uses throughout human's history. In Egypt, distribution of date palm trees, covers a large area extends from Aswan to north Delta, beside the oases of Siwa, Bahriya, Farafra, Kharga and Dakhla. The date palms in Egypt of important horticultural crops where the number of palms in Egypt almost (12.5) million palm trees produce about (1.5) million tons a year are considered Egypt's the first date producing according to statistics from the FAO (2013-2014). Palm tree has many advantages as it arises many important environmental industries, which are a major source of income for the people in those areas. Fruits highly nutritious fruit are rich and poor food.

The red palm weevil, Rhynchophorus ferrugineus (Oliv.) (Coleoptera: Curculionidae), is one of the worst pests for palms, since it can completely destroy the plant (Abelardo et al., 2010). It has its home in south and southeast Asia where it is a key pest of coconut (Cocos nucifera) and is reported from $15 \%$ of the coconut growing countries worldwide (Faleiro, 2006). The weevil was recorded in Seri Lanka, Indonesia, Burma, Punjab, and Pakistan (Laskshmanan et al., 1972). The insect is a major pest of date palm in some of the Arabian Gulf States including Saudi Arabia, United Arab Emirates, Sultanate of Oman, and Egypt (Cox, 1993, Abraham et. al. 1998). The agro climatic conditions prevalent in this region and the unique morphology of the crop, coupled with intensive modern date palm farming, have offered the pest an ideal ecological habitat (Abraham et al., 1998). Currently, RPW is reported from all the continents with ecological niche modeling predicting its spread to new regions (Fiaboe, et al., 2012). The whole larval life cycle of the weevil is concealed within the palm. For P. dactylifera, attacks start when females lay eggs on wounds, or cracks and crevices on the trunk around the collar region near the roots or off shoots, or the base of fronds in young date palms, with trees less than 20 years old being most preferred (Dembilio et al., 2012; Faleiro et al., 2012). Males of RPW produce an aggregation pheromone that attract both males and females weevils, and was first identified and synthesized by Hallett et al., (1993). Many approaches have been proposed to control RPW

The present work was carried out to investigate the following aspects: Population fluctuation of Red Palm Weevil $R$. ferrugineus during years (2013-2014) by using pheromone traps. Effect of Temp. \& R.H.\% on $R$. ferrugineus population in Baharia Oases. Sex ratio of red palm weevil adults attracted to the traps.

\section{MATERIALS AND METHODS}

This work was carried out during January 2013 to December 2014 in Baharia Oases, Giza Governorate Egypt. Its aim was to study population fluctuation of adults of (RPW) Rhynchophorus ferrugineus (Oliv.) by using Pheromone traps.

Five pheromone traps were distributed in the investigated orchards (5 feddan). Pheromone traps designed and applied according to (Hanounik et al., 2000), the pheromone trap consists of ten liter plastic container with four circular holes in the cover and six holes near the upper edge of side walls. Each trap contained dispenser of the $R$. ferrugineus male aggregation pheromone containing $700 \mathrm{mg}$ of the active ingredient (4-Methyl-5-Nonanol (9 parts) + 4Methyl-5-Nonanon (1 part) (pheromone lure was manufactured by Chim Tica international S. A. company, Costa Rica. Trade Name PO28 Ferrolure+,700 mg lure, consists of a mixture of 4methyl 5- nonanol and 4-methyl 5-nonanone (9:1 part purity of both componenst a $95 \%$ release rate $3-10$ $\mathrm{mg} /$ day) . dispenser of the kairomone contanining $45 \mathrm{ml}$ of the active ingredient Ethyl Acetate in gel, at $95 \%$ minimum purity, release rate $200-400 \mathrm{mg} /$ day colorant added ( kairomone manufactured by Chim Tica international S.A. company, Costa Rica. Trade Name PO80A Weevil magent $45 \mathrm{~mL}$ lure) and $5 \mathrm{~L}$ 
of water. The outer surface of the bucket was rough with plastic net $(1-2 \mathrm{~mm})$ to help the weevils cling to the trap and enter. The water was replenished every two weeks to keep sufficient moisture in each trap to avoid escaping of the adult and it helps the insects to survive. The pheromone was replaced every two months in summer and replaced every three months in winter. The distance between traps was $100 \mathrm{~m}$ and each trap was 4 $\mathrm{m}$ away from date palm trees (to avoid that any adult could missed the trap and lay eggs on the palm tree), put traps in the shade to avoid water evaporation Al-Saoud et al, (2010). Every two weeks traps were checked and trapped weevils were collected, counted, sexed and recorded. The climatic factors such as daily mean of temperature and daily mean of R.H \% during studied period started from January 2013 and extended to December 2014 were obtained from Central Laboratory for Agricultural Climate, two weeks earlier from the insect inspection or sampling.

Statistical analysis: Simple correlation and multiple regression values of daily mean temperature \& R.H. \% on the population activity of RPW adults during $2013 \&$ 2014 were undertaken and subjected to statistical analysis of computer ( SAS) program Institute (1998).

\section{RESULTS AND DISCUSSION}

\section{1- Population fluctuations of RPW $R$. ferrugineus on date palm plantation during 2013 \& 2014:}

Data tabulated in Table (1) and graphically illustrated in Figures $(1 \mathrm{a} \& \mathrm{~b})$ showed that population activity of RPW adult during the tested period from January 2013 to December 2014 seasons. The weevils were first observed in traps with relatively few numbers in January during the first season (3.2 adults/ trap) and second season (3.0 adults / trap). Then the number of captured adults increased gradually and fluctuated to give two peaks in both years. In the first year (2013), the first peak recorded at the second week of April, the average number of $R$. ferrugineus adults per one trap was (11.6 adults/ trap) .The second peak recorded at the second week of October with the mean number of 12.8 adults / trap (the highest value). In the second year (2014), seasonal prevalence of $R$. ferrugineus population had approximately similar trend of abundance as in the first year recorded two peaks Table (2) and (Figs. 2a\&b). The weevils appeared in January and increased gradually in numbers, fluctuated to give two peaks, the first peak of abundance recorded at the second week of March with 11.4 adults/ trap (the highest value). The second peak was recorded in the second week of September (10.6 adults / trap). Data obtained revealed that the reliable number of captured red palm weevil occurred during periods which extended from March until November. The obtained results are in agreement with the findings of Hashim et al. (2013) who indicated that weevils of $R$. ferrugineus were found to be existed in pheromone traps all year round on the course of two successive seasons 2007 2008 and $2008-2009$. Two flight peaks were recorded during both years of study, the $1^{\text {st }}$ peak was recorded in September, the $2^{\text {nd }}$ peak occurred in March. El-Shafi
(2011) indicated that emerging adults continue throughout the year, and stated that the lowest adults population was recorded during December and January. In Egypt El Sebay et al. (2010) and Saleh et al. (2012) monitored two peaks of population abundance of red palm weevil at year. In the United Arab Emirates Abbas et al. (2006) reported that the population fluctuation of $R$. ferrugineus, using the aggregation pheromone traps, increased gradually from January to reach its peak in March, April, or May. In summer (June-September), as the temperature reaches an average of $42.8^{\circ} \mathrm{C}(39-48)$ during day, the population of RPW decreases. During this period the weevils may dwell in the infested date palms or inhabit the soil seeking shade and shelter Abbas (2000). Zahra (2014) showed that RPW existed all over the year and there are four peaks during the tested year 2012-2013, the mean of the total captured adults at the beginning of December 2012 was 6.40 adults/ trap then it decreased gradually to recorded the lowest average of captured RPW adults (2.30 adults/ trap) at $15^{\text {th }}$ Jan. 2013, and it fluctuated to recorded four peaks the first ( 17.40 adults/ trap) recorded at $15^{\text {th }}$ April 2013, the second peak (12.80 adults/ trap) recorded at $30^{\text {th }}$ May 2013, the third and the highest peak (20.60 adults/ trap) recorded at $15^{\text {th }}$ July and the fourth peak (10.40 adults/ trap) recorded at $15^{\text {th }}$ Sep. 2013 it is the last peak. Osman (2015) showed that the adult of $R$. ferrugineus existed and fluctuated all over the year with four peaks. The first peak at the first week of March and the second peak at the second week of May. The third peak at the last week of June, while the fourth peak recorded at the first week of October at the first year 2011. The second year 2012, first peak recorded at the first week of March, the second peak at the second week of April, the third peak at the last week of May, while the fourth peak at the last week of September.

Table 1. Fortnightly mean numbers of $R$. ferrugineus which attracted to aggregation pheromone trap in Baharia Oases in Giza Governorate during 2013.

\begin{tabular}{|c|c|c|c|c|c|}
\hline \multirow[t]{2}{*}{ Inspection date } & \multicolumn{3}{|c|}{$\begin{array}{l}\text { Average of RPW captured } \\
\text { adult / aggregation } \\
\text { pheromone trap }\end{array}$} & \multicolumn{2}{|c|}{ Mean } \\
\hline & Male & Female & Total & Temp. ${ }^{\circ} \mathrm{C}$ & R.H.\% \\
\hline $15-01-13$ & 0.6 & 2.6 & 3.2 & 13.3 & 40.4 \\
\hline $29-01-13$ & 1.0 & 2.2 & 3.2 & 14.6 & 26.6 \\
\hline $12-02-13$ & 1.4 & 3.2 & 4.6 & 14.7 & 27.0 \\
\hline $26-02-13$ & 2.6 & 4.4 & 7.0 & 15.9 & 19.6 \\
\hline $12-03-13$ & 2.4 & 6.4 & 8.8 & 19.3 & 21.0 \\
\hline $26-03-13$ & 3.6 & 7.4 & 11.0 & 20.1 & 21.0 \\
\hline $09-04-13$ & 2.8 & 8.8 & 11.6 & 22.9 & 13.3 \\
\hline $23-04-13$ & 2.2 & 8.0 & 10.2 & 19.6 & 24.0 \\
\hline $07-05-13$ & 1.8 & 8.4 & 10.2 & 25.9 & 16.4 \\
\hline $21-05-13$ & 1.4 & 5.0 & 6.4 & 26.6 & 18.1 \\
\hline $04-06-13$ & 1.4 & 4.6 & 6.0 & 30.6 & 14.4 \\
\hline $18-06-13$ & 1.2 & 2.4 & 3.6 & 28.3 & 19.5 \\
\hline $02-07-13$ & 1.6 & 2.8 & 4.4 & 29.3 & 21.6 \\
\hline $16-07-13$ & 1.0 & 2.4 & 3.4 & 28.5 & 27.3 \\
\hline $30-07-13$ & 1.0 & 3.4 & 4.4 & 29.1 & 21.4 \\
\hline $13-08-13$ & 2.0 & 3.0 & 5.0 & 31.1 & 16.6 \\
\hline $27-08-13$ & 2.2 & 4.4 & 6.6 & 30.1 & 24.5 \\
\hline $10-09-13$ & 2.4 & 6.0 & 8.4 & 28.9 & 27.4 \\
\hline $24-09-13$ & 2.6 & 8.2 & 10.8 & 29.6 & 25.1 \\
\hline $08-10-13$ & 3.2 & 9.6 & 12.8 & 24.6 & 20.4 \\
\hline $22-10-13$ & 1.8 & 4.4 & 6.2 & 23.6 & 35.6 \\
\hline $05-11-13$ & 2.6 & 3.0 & 5.6 & 20.2 & 45.4 \\
\hline $19-11-13$ & 1.0 & 2.4 & 3.4 & 19.5 & 46.1 \\
\hline $03-12-13$ & 1.4 & 1.8 & 3.2 & 21.8 & 32.3 \\
\hline $17-12-13$ & 1.2 & 1.8 & 3.0 & 13.6 & 49.8 \\
\hline Total & 46.4 & 116.6 & 163.0 & 581.5 & 654.8 \\
\hline Mean & 1.9 & 4.7 & 6.5 & 23.3 & 26.2 \\
\hline
\end{tabular}




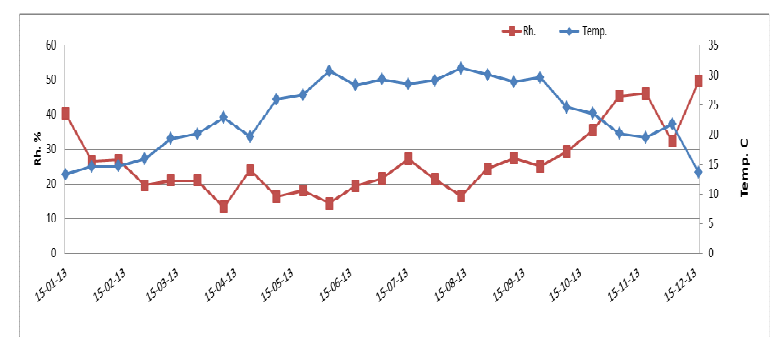

Fig. 1a. Daily mean of temperature and relative humidity in Giza Governorate during 2013.

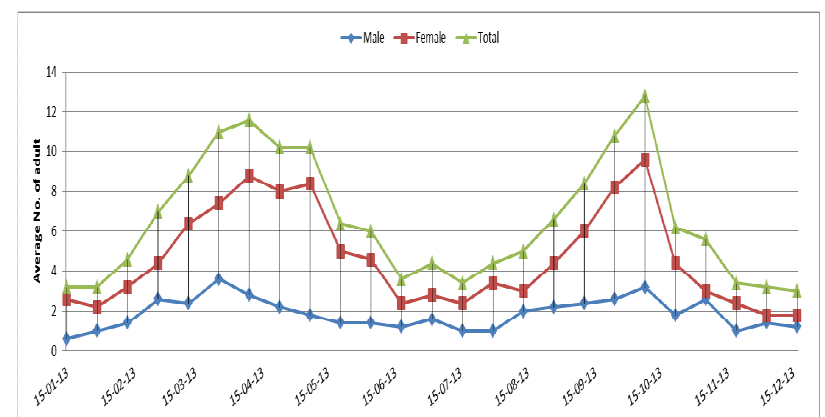

Fig. 1b. Fortnightly mean numbers of $R$. ferrugineus which attracted to aggregation pheromone trap in Baharia Oases in Giza Governorate during 2013.

Table .2. Fortnightly mean numbers of $R$. ferrugineus which attracted to aggregation pheromone trap in Baharia Oases in Giza Governorate during 2014.

\begin{tabular}{|c|c|c|c|c|c|}
\hline \multirow[t]{2}{*}{ Inspection date } & \multicolumn{3}{|c|}{$\begin{array}{c}\text { Average of RPW captured } \\
\text { adult / aggregation } \\
\text { pheromone trap }\end{array}$} & \multicolumn{2}{|c|}{ Mean } \\
\hline & Male & Female & Total & Temp. ${ }^{\circ} \mathrm{C}$ & R.H. \% \\
\hline 15-01-14 & 0.4 & 2.6 & 3.0 & 13.9 & 44.0 \\
\hline $29-01-14$ & 0.6 & 2.4 & 3.0 & 15.3 & 34.1 \\
\hline $12-02-14$ & 1.6 & 4.2 & 5.8 & 15.5 & 33.6 \\
\hline $26-02-14$ & 3.0 & 7.6 & 10.6 & 16.7 & 38.9 \\
\hline $12-03-14$ & 3.2 & 8.2 & 11.4 & 24.1 & 27.5 \\
\hline $26-03-14$ & 2.4 & 7.8 & 10.2 & 18.5 & 34.8 \\
\hline 09-04-14 & 1.8 & 6.2 & 8.0 & 21.6 & 22.6 \\
\hline $23-04-14$ & 2.6 & 4.4 & 7.0 & 23.7 & 23.7 \\
\hline $07-05-14$ & 2.4 & 4.2 & 6.6 & 26.8 & 21.1 \\
\hline $21-05-14$ & 2.0 & 2.4 & 4.4 & 25.2 & 20.0 \\
\hline $04-06-14$ & 1.6 & 3.2 & 4.8 & 28.1 & 18.4 \\
\hline $18-06-14$ & 1.0 & 2.2 & 3.2 & 29.1 & 20.9 \\
\hline $02-07-14$ & 1.2 & 2.4 & 3.6 & 29.9 & 24.1 \\
\hline $16-07-14$ & 1.6 & 2.6 & 4.2 & 30.7 & 25.0 \\
\hline $30-07-14$ & 2.2 & 5.0 & 7.2 & 30.9 & 24.9 \\
\hline $13-08-14$ & 2.2 & 5.2 & 7.4 & 31.4 & 26.9 \\
\hline $27-08-14$ & 3.0 & 5.8 & 8.8 & 31.1 & 26.7 \\
\hline $10-09-14$ & 1.8 & 8.8 & 10.6 & 30.6 & 24.4 \\
\hline 24-09-14 & 2.2 & 7.4 & 9.6 & 29.0 & 30.8 \\
\hline $08-10-14$ & 2.4 & 5.6 & 8.0 & 26.4 & 34.6 \\
\hline $22-10-14$ & 2.6 & 3.6 & 6.2 & 24.1 & 33.1 \\
\hline $05-11-14$ & 2.0 & 2.6 & 4.6 & 22.5 & 26.6 \\
\hline $19-11-14$ & 1.4 & 2.6 & 4.0 & 20.4 & 38.2 \\
\hline $03-12-14$ & 1.0 & 2.0 & 3.0 & 17.6 & 45.9 \\
\hline Total & 46.2 & 109.0 & 155.2 & 583.2 & 700.9 \\
\hline Mean & 1.9 & 4.5 & 6.5 & 24.3 & 29.2 \\
\hline
\end{tabular}

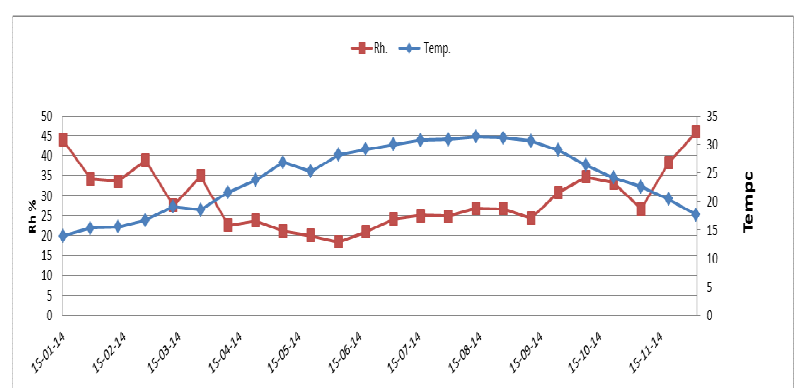

Fig. 2a. Daily mean of temperature and relative humidity in Giza Governorate during 2014.

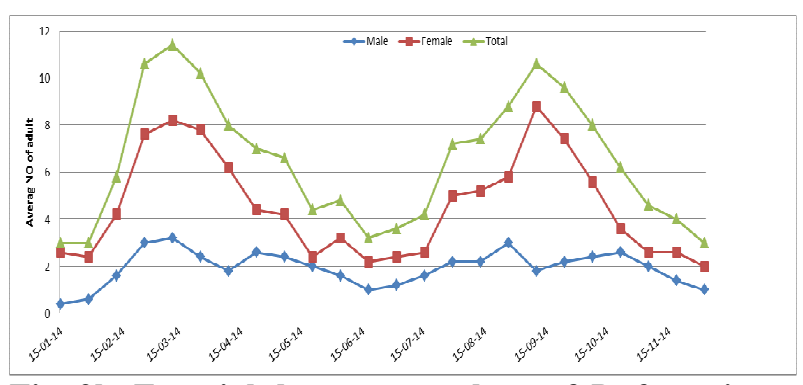

Fig. 2b. Fortnightly mean numbers of $R$. ferrugineus which attracted to aggregation pheromone trap in Baharia Oases in Giza Governorate during 2014.

2. The effect of weather factors on the population activity of RPW adults during 2013\& 2014 in Baharia Oases:

The present study showed that the effect of daily mean temperature and daily mean relative humidity on the population activity of RPW.

Effect of daily mean temperature on the population activity of $R$. ferrugineus adults during $2013 \& 2014$.

The obtained results presented in Table (3) shows the correlation coefficient ( $r$ ) between daily mean temperature and the population abundance of RPW in 2013 and 2014. There was significant positive correlation in winter 2013\& 214, spring 2014 and autumn $2013 \& 2014(\mathrm{r}$ value $=0.962 \& 0.779,0.822$ and $0.662 \& 0.982$ respectively), and significant negative correlation in spring and summer 2013 ( $\mathrm{r}$ value $=-0.613$ and $-0,736$ respectively). While was nonsignificant positive correlation in summer 2014 ( $\mathrm{r}$ value $=0.497)$.

Effect of daily mean R.H. \% on the population abundance of $R$. ferrugineus adults during $2013 \&$ 2014.

As shown in Table (3) the correlation coefficient between daily mean R.H.\% and the population abundance of RPW in 2013 and 2014. There was significant negative correlation in winter \& spring 2013 and autumn 2014 ( $\mathrm{r}$ value $=-0.766 \&-0.656$ and -0.520 respectively). While there was significant positive correlation in spring 2014, summer and autumn 2013 (r value $=0.657,0.717$ and 0.794 respectively). On the other hand R.H. had non significant positive correlation in winter and summer 2014 ( $\mathrm{r}$ value $=0.476$ and 0.300 respectively). 
Table 3. Simple correlation and multiple regression values of daily mean temperature \& R.H. \% on the population fluctuation of $R$. ferrugineus adults during $2013 \& 2014$.

\begin{tabular}{|c|c|c|c|c|c|c|c|c|c|}
\hline \multirow{2}{*}{ Season } & \multirow{2}{*}{ Years } & \multirow{2}{*}{ Factors } & \multicolumn{2}{|c|}{ Correlation } & \multicolumn{5}{|c|}{ Multiple regression } \\
\hline & & & $\mathbf{r}$ & $\mathbf{p}$ & b & p & F. value & p & E.V.\% \\
\hline \multirow{5}{*}{ Winter } & & Daily mean temp. & 0.962 & 0.0001 & 0.983 & 0.0050 & \multirow{2}{*}{31.24} & \multirow{2}{*}{0.0015} & \multirow{2}{*}{92.5} \\
\hline & 2013 & Daily mean R.H.\% & -0.766 & 0.0266 & -0.050 & 0.8300 & & & \\
\hline & & Daily mean temp. & 0.779 & 0.0477 & 1.132 & 0.1473 & \multirow{2}{*}{2.88} & \multirow{2}{*}{0.2003} & \multirow{2}{*}{65.7} \\
\hline & 2014 & Daily mean R.H.\% & 0.476 & 0.3395 & 0.255 & 0.5539 & & & \\
\hline & & Daily mean temp. & -0.613 & 0.0422 & -0.829 & 0.8760 & \multirow{2}{*}{5.96} & \multirow{2}{*}{0.0631} & \multirow{2}{*}{74.8} \\
\hline \multirow{3}{*}{ Spring } & 2013 & Daily mean R.H.\% & -0.656 & 0.0391 & -0.344 & 0.0716 & & & \\
\hline & & Daily mean temp. & 0.822 & 0.0444 & -0.452 & 0.2073 & \multirow{2}{*}{3.40} & \multirow{2}{*}{0.1693} & \multirow{2}{*}{69.3} \\
\hline & 2014 & Daily mean R.H.\% & 0.657 & 0.0462 & 0.174 & 0.7076 & & & \\
\hline \multirow{5}{*}{ Summer } & & Daily mean temp. & -0.736 & 0.0234 & -1.545 & 0.8408 & \multirow{2}{*}{0.60} & \multirow{2}{*}{0.6744} & \multirow{2}{*}{54.5} \\
\hline & 2013 & Daily mean R.H.\% & 0.717 & 0.0220 & 0.090 & 0.9519 & & & \\
\hline & & Daily mean temp. & 0.497 & 0.3149 & 5.033 & 0.3902 & 070 & 05626 & 218 \\
\hline & 2014 & Daily mean R.H.\% & 0.300 & 0.5623 & -1.212 & 0.6159 & 0.10 & $0.50<0$ & 31.8 \\
\hline & & Daily mean temp. & 0.662 & 0.0420 & 0.013 & 0.9835 & \multirow{2}{*}{2.56} & \multirow{2}{*}{0.2244} & \multirow{2}{*}{63.0} \\
\hline \multirow{3}{*}{ Autumn } & 2013 & Daily mean R.H.\% & 0.794 & 0.0292 & -0.264 & 0.2999 & & & \\
\hline & 2014 & Daily mean temp. & 0.982 & 0.0005 & 0.706 & 0.0001 & 47,47 & $0 \Omega \cap 01$ & 008 \\
\hline & 2014 & Daily mean R.H.\% & -0.520 & 0.0494 & 0.094 & 0.0041 & 42.42 & 0.0001 & 99.8 \\
\hline
\end{tabular}

$\mathbf{r}=$ simple correlation coefficient value $\quad \mathbf{b}=$ Multiple regression coefficient value

$P=$ probability Level
E.V.: Explained variance

Combined effect of weather factors (temperature $\&$ R.H.\%) on the population abundance of RPW during 2013\& 2014:

The effect of combination of daily mean temperature and R.H.\% on the population abundance of RPW during 2013\& 2014 was presented as explained variance (E.V.\%) which was 92.5 \& 65.7 in winter 2013 and 2014 respectively and 74.8 (2013) and 69.3 (2014), in spring, in summer 2013 and 2014 was 54.5 \& 31.8 respectively, while in autumn 2013 (63.0) and 2014 (99.8 ) Table (3). It is clear that the two investigated factors were responsible for high percentages for the variability in the population of $R$. ferrugineus in 2013 and 2014. These results is in harmony with findings of Faleiro (2005) who found that maximum temperature had a significant impact on the weevil activity in India, the maximum temperature was positively correlated $(\mathrm{r}=$ 0.51) with weevil captures. El-Shafi (2011) indicated that there was significant positive correlation between weather factor (mean daily temperature) and the population abundance of RPW during the two tested years. While relative humidity had negative correlation. Also the data are in agreement with. Zahra (2014) who stated that there was non-significant positive correlation between daily mean temperature and the population abundance of RPW, while there was a significant negative correlation between the means of daily relative humidity and the population abundance of the RPW adults during the tested year. Osman (2015) showed that there was non-significant positive correlation between daily mean temperature and the population abundance of RPW, while the correlation between means of daily relative humidity and the population abundance of the RPW adults was non-significant negative correlation during the same tested year 2011. Also the results showed that there was significant positive correlation between daily mean temperature and the population abundance of RPW, while the correlation between means of daily relative humidity and the population abundance of the RPW adults was significant negative correlation during the same tested year 2012 .

\section{Sex ratio of $R$. ferrugineus attracted to aggregation pheromone traps in 2013\& 2014:}

Data obtained in Fig. (3) illustrate that the sex ratio of captured adults using aggregation pheromone traps. The numbers of attracted females were higher than males in all months of two tested years (2013\& 2014). The sex ratios of male to female were $1: 2.5$ and 1: 2.4 at 2013 and 2014 respectively. The results obtained are similar with those recorded by A1-Saoud (2007) who stated that the adults of RPW were presented throughout the year, and the number of females was higher than the number of males. In Spain Sansano et al. (2008) found that during one year, the average number of trapped female was 2.5 times higher than the male's one. El-Sebay et al. (2010) observed that number of RPW female attracted to aggregation pheromone traps was considerable high than males during two successive years (2008 and 2009). Zahra (2014) found that the numbers of females attracted to aggregation pheromone traps were generally twice as that of males. The sex ratios of male to female were 33.4: 66.6 during the tested year 2012-2013. 

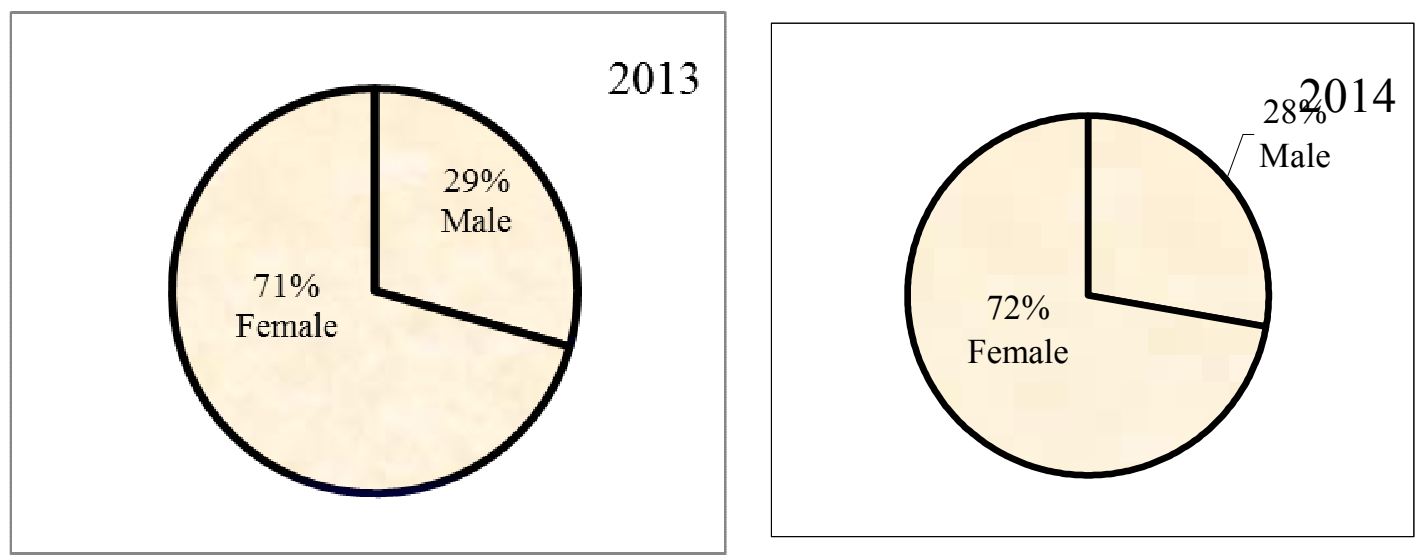

Fig. 3. Sex ratio (males: females) of $R$. ferrugineus obtained from aggregation pheromone traps in Baharia Oases during 2013 \& 2014.

\section{REFERENCE}

Abbas, M. S. T.; Hanounik, S. B.; Shahdad, A. S. and Al-Bagham, S. A. (2006): Aggregation pheromone traps, a major component of IPM strategy for the red palm weevil, Rhynchophorus ferrugineus date palms (Coleoptera: Curculionidae) . J. P. Sci. 79 (2):69-73.

Abbas, M.K. (2000): Studies on the red palm weevil. $M$. Sc. Thesis, Fac. Agric., Zagazig Univ., 104pp.

Abelardo, G.; Vicente, R.; Enrique, M.; Gervasio T. and Maria, D. (2010): Development of a bioacoustic sensor for the early detection of Red Palm Weevil (Rhynchophorus ferrugineus Olivier). Crop Prot. 29(7):671-676.

Abraham, V.A,;Al-Shuaibi, M.A.;Faleiro, J.R.; Abozuhairah, R.A. and Vidyasagar P. S. (1998): An integrated management approach for red palm weevil Rhynchophorous ferrugineus Olive. A key pest of date palm in the Middle East. J. Agric. Sci. 3:77-83.

Al-Saoud, A. H. (2007): Importance of date fruit in red palm weevil, Rhynchophorus ferrugineus Olivier (Coleoptera: Curculionidae) aggregation pheromone traps. Acta Horticulturae; (736):405413.

Al-Saoud, A.H.; Al-Deeb, M.A. and Murchie, A.K. (2010): Effect of color on the trapping effectiveness of red palm weevil pheromone traps. J. Entomol., 7: 54-59.

Cox, M. L. (1993): Red palm weevil, Rhynchophorus ferrugineus, in Egypt. FAO-Plant-ProtectionBulletin 41: 1, 30-31.

Dembilio, O.; Tapia, G.V.; Téllez, M. M. and Jacas, J. A. (2012): Lower temperature thresholds for oviposition and egg hatching for the red palm weevil, Rhynchophorus ferrugineus (Coleoptera: Curculionidae), in a Mediterranean climate. B. Entomol. Res. 102:97-102.
El-Sebay, Y. M. A.; Abbass, M. K. and El-Shezly, M. M. (2010): Seasonal abundance and population trends of red palm weevil, Rhynchophorus ferrugineus oliver (coleopteran: curculioinidae). J. Plant Protection and Pathology, Mansoura University, 1(8): 577- 583.

El-Shafi, M. K. W. (2011): Ecological Studies on the Red Palm Weevil, Rhynchophorus ferrugineus (Oliv). (Curculionidae: Coleoptera). M. Sc. Thesis, Fac. Agric., Benha Univ., Egypt, 180pp.

Faleiro, J. R. (2005): Pheromone technology for the management of red palm weevil Rhynchophorus ferrugineus(Oliv.) (Coleoptera: Curculionidae) a key pest of coconut, Technical Bulletin, ICAR Research Complex for Goa. 4: 40.

Faleiro, J. R. (2006): A review of the issues and management of the red palm weevil Rhynchophorus ferrugineus (Coleoptera: Curculionidae) in coconut and date palm during the last one hundred years. International Journal of Tropical Insect Science, 26:135-154.

Faleiro, J.R.; Abdullah, B.A.; El-Bellaj, M.; Al Ajlan, A. M. and Oihabi, A. (2012): Threat of red palm weevil, Rhynchophorus ferrugineus (Olivier) to date palm plantations in North Africa. Arab J. Plant Prot. 30:274-280.

Fiaboe, K. K. M,; Peterson, A. T.; Kairo, M. T. K. and Roda, A. L. (2012): Predicting the potential worldwide distribution of the red palm weevil Rhynchophorus ferrugineus (Olivier) (Coleoptera: Curculionidae) using ecological niche modeling. Fla. Entomol. 95:559- 673.

Hallett, R. H.; Oehlschlager, A. C.; Gries, G.; Angerelli, N. P. O.; Ai-Shareq, R. K.; Gassuma, M. S. and Borden, J. H. (1993): Field-testing of aggregation pheromones of two Asian palm weevils Pipoc Porim International Palm Oil Congress "Update and Vision". 20-25 September, 1993. Kualalumpur, Malaysia. 
Hanounik S. B, M. Salem, G. Hegazy, O. E. Al Mohanna, M. Al Hegi and H. Al Zahir (2000): Development of a new food-baited aggregation pheromone/ kairomone trapping system for the red palm weevil, Rhynchophorus ferrugineus (Oliv.) Proceedings of First workshop on Control of Date Palm Weevil, King Faisal University, Kingdom of Saudi Arabia,113-125.

Hashim, S. M.; Abdullah, F. F. and Tawfik, H. M. (2013): monitoring studies of the red palm weevil Rhynchophorus ferrugineus using pheromone traps in palm tree orchards. AFPP - Palm Pest Mediterranean Conference Nice - 16, 17 and 18 January.

Laskshmanan, P. L.; Subba Rao, P. B. and Subramanian, T. R. (1972): A note on the control of the coconut red palm weevil Rhynchophorus ferrugineus with certain new chemicals. Madras Agric. Journal 59: 638-639.

Osman, S. H. K. (2015): Studies on red palm weevil and its control. M.Sc. Thesis, Fac. Agric., Al-Azhar Univ., 99pp.
Saleh, M. M. E.; Abdel-Monim, A. S. H. and El-Kholy, M. Y. (2012): Population of adults of the red palm weevil, Rhynchophorus ferrugineus (Coleoptera: Curculionidae) in date palm farms in Ismailia governorate, Egypt. J. Am. Sci.; 8(12):440-443.

Sansano, M.; Gómez, S.; Ferry, M. and Díaz, G., (2008): Ensayos de campo para la mejora de la eficacia de las trampas de captura de Rhynchophorus ferrugineus, Olivier (Coleoptera: Dryophthoridae), picudo rojo de la palmera.Boletín de Sanidad Vegetal Plagas, 34 (1): 135 145.

Zahra, A. A. A. (2014): Studies on red palm weevil Rhynchophorus ferrugineus. M. Sc. Thesis, Fac. Agric., Al-Azhar Univ., $111 \mathrm{pp}$.

Zaid, A. and Hegarty, V. (2006): Focus on: Producing date palm trees with improved fruit yield, short height, and resistance to Bayoud disease. "The Third International Conference on Date Palm", 20 - 22 Feb. Emirates Palace Hotel, Abu Dhabi, UAE.

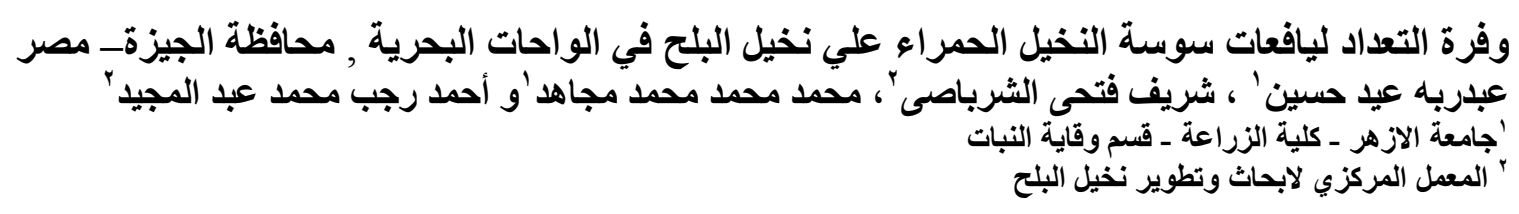

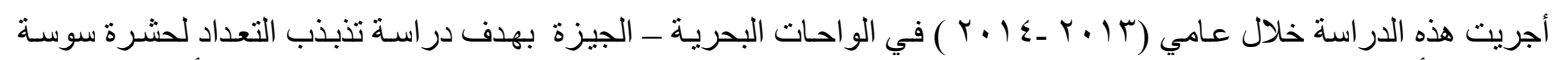

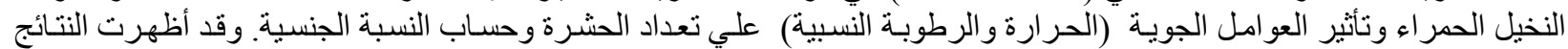

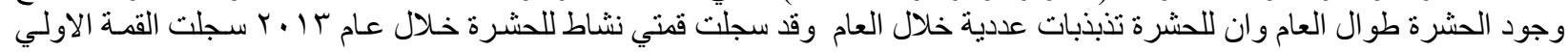

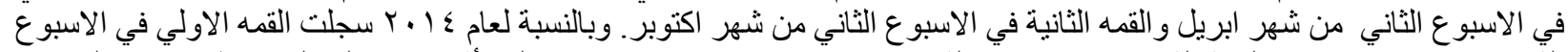

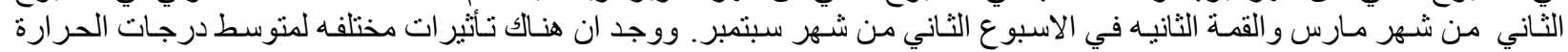

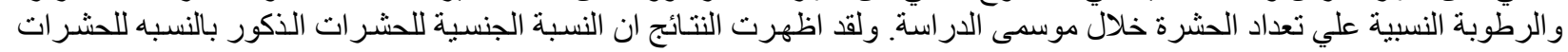
الاناث (1) 